\title{
Ki-67 Labeling Index
}

National Cancer Institute

\section{Source}

National Cancer Institute. Ki-67 Labeling Index. NCI Thesaurus. Code C157250.

The percentage of cells in a sample that are dividing that is determined by immunohistochemical staining techniques using MIB-1 antibody (anti-Ki-67 protein antibody). 